\section{Old images record landscape change through time}

Paul R. Bierman, pbierman@uvm.edu, Jehanna Howe, Department of Geology and Natural Resources, University of Vermont, Burlington, Vermont 05405, USA,

Elizabeth Stanley-Mann, Michala Peabody, Jens Hilke, and Christine A. Massey, Department of Geology, University of Vermont, Burlington, Vermont 05405, USA

\begin{abstract}
Historical photographs are a powerful tool for examining and understanding the distribution of surficial processes, both physical and biological, on the timescale of decades and centuries. Such imagery is particularly valuable for understanding human-landscape interaction. Here, we present several examples of quantitative, image-based, landscape-scale analyses made using hundreds of different images, each taken at a different place. This analysis takes advantage of a large, searchable, Web-based image archive that contains enough images to allow testing of specific hypotheses regarding landscape change over time. For example, analysis of Vermont landscape images dated between 1860 and 1990 demonstrates that erosion is more common in clearcut areas than in partially or wholly forested sites. We find that the quality of riparian buffers increased slowly over the past 184 years, with a dramatic improvement after 1980. Oblique aerial imagery taken after the 1927 flood of record and recently rephotographed demonstrates the frequency of nearchannel land-use change over the past century. Together, these examples show the value of readily searchable image archives in allowing scientists, planners, and land managers to approach problems of significant societal relevance.
\end{abstract}

Keywords: Erosion, landslide, flood, hazard, mapping, historical landscapes.

\section{INTRODUCTION}

For millennia, people have altered the landscapes on which they are born, live, and die. Such alteration began with clearance of valleys and slopes for agriculture at least 9000 years ago and was soon followed by the construction of roads, buildings, and cities (Hooke, 2000). Today, people are the most moving more mass every year than all other natural processes combined (Cronon, 1996; Hooke, 1994).

There is clearly a linkage between human actions and landscape response in areas as diverse as desertification (Zheng and Eltahir, 1997), road building (Wemple et al., 2000), and in the relationship between clear-cutting and mass movements (Montgomery et al., 2000). Such linkages have been made for more than a century. Marsh, writing Man and Nature in the 1850s, lamented the clearing of hillslopes and the erosion that followed. Beginning in the 1960s, the environmental movement brought these impacts clearly into the public eye, and debate has raged ever since over logging, road building on wild lands, and the alteration and restoration of river channels in the context of protecting endangered species (Montgomery, 2004).

Geoscientists are key providers of data for environmental management and disaster prevention because they understand relevant deep earth and surficial processes (Schneiderman, 2000). Without denying the value of both physical and mathematical models, much of what we know about Earth is rooted in the mapping of rock and surficial materials (e.g., volcanic mudflow deposits). Such mapping, often coupled with geochronology, lets geologists infer both the spatial and temporal distribution of near-surface geologic processes over millennia.

This paper presents a different way of looking back through time and space to understand both the style and tempo of landscape change. Here, we show that a searchable archive of historical images can be used to understand the distribution of surface processes and landscape active geomorphic force on the planet, characteristics. By examining cultural features and actions, we can infer how societal changes have shaped landscapes as well as how landscapes have shaped societies. Our approach is applicable over much of the past 200 years, providing a bridge between short-term instrumental records and geologic techniques that are often more useful over longer time frames. The approach we lay out could easily be applied to different questions in a wide variety of tectonic and climatic zones.

\section{THE LANDSCAPE CHANGE PROGRAM VIRTUAL ARCHIVE}

The Landscape Change Program is a community archive containing more than 10,000 images of Vermont landscapes from before 1810 to the present. It is freely available at http://uvm.edu/ perkins/landscape. Each image in the archive is key-worded, and more than $60 \%$ of the holdings are now described in detail, allowing efficient online searching of the archive. More than half the images are dated to the year and $>98 \%$ are located to the town level. The earliest images are drawings; the first reliably dated photographs are from the 1850s. As of January 2005, the number of dated images in the collection increases exponentially between 1810 and 1910, peaks in the 1920s, and then declines. Nearly 600 images have been rephotographed since the year 2000, providing a contrasting view of earlier landscape imagery. The distribution of images over time reflects both the mid1800s' popularization of photography and the particular archives from which many of the images were acquired: a collection of stereoviews (late 1800s), the State Agency of Transportation (1910-1970), and the State Division of Tourism (1960-1970).

The Landscape Change collection is particularly rich in images of rural areas, typically underrepresented in many historical archives. Such images typically show subjects of interest to natural scientists. For example, by late 2004, the archive contained $>400$ images of rivers, $>340$ images of eroding hillslopes, >660 images of floods and flood damage, $>200$ images of quarrying and mining, $>1000$ images of bridges, and >3000 images of roads (Fig. 1). 

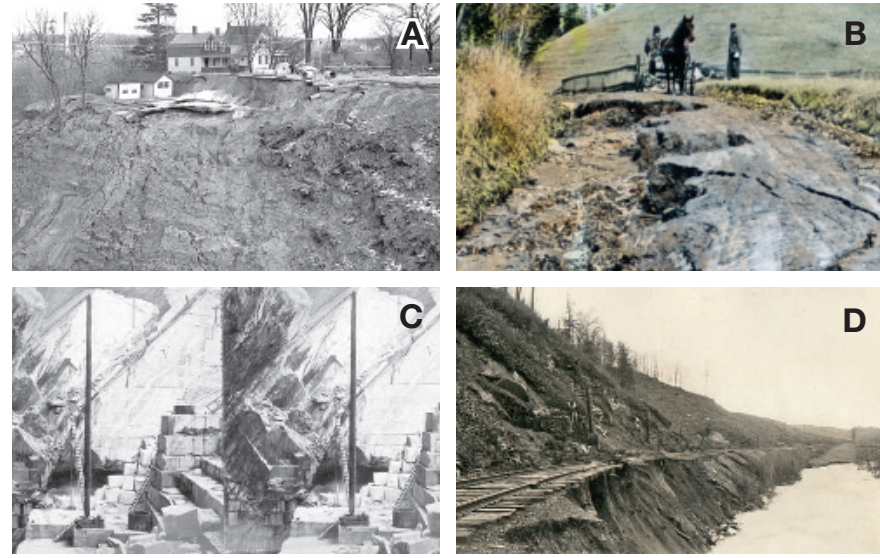

Figure 1. Images from the Landscape Change Program archive depicting landscape features, changes, and processes of interest to geoscientists. (A) Photograph of a large landslide that occurred in Burlington, Vermont, in December 1955. Slide is in glacial-lacustrine and glacial-marine silt and clay and was triggered by a leaking drain pipe. LS01781, image property of Bailey Howe Library, Special Collections, University of Vermont. (B) Hand-colored lanternslide of a horse and buggy on a washed-out road in St. Johnsbury, Vermont, 1914. LS06469, image property of Vermont State Archives. (C) Quarrying marble, West Rutland, Vermont. Stereoview shows structure of rock in high wall of quarry. LS05073, image property of Bailey Howe Library, Special Collections, University of Vermont. (D) Photograph showing erosion undercutting railroad tracks in Barton, Vermont, after 1927 flood of record. Slopes above tracks are unvegetated and failing. LS02477, image property of Old Stone House Museum.

Vermont has an exceptionally strong, town-centered governmental system, which favors the preservation of imagery at a local level in town halls and historical societies. Thus, both Vermont and the Landscape Change Program archive have exceptional documentation of major cultural transitions (forest clearance, industrialization, suburbanization, and road building) stretching back two centuries. It is these changes that have shaped both today's landscape and society as we know it. In many ways, Vermont is also physiographically representative of much of the United States, a humid, temperate sample of America where metamorphic, sedimentary, and igneous rocks crop out both in rugged mountains and flatlying low lands.

\section{PHOTOGRAPHS AND GEOLOGY}

Many kinds of scientific analysis and hypothesis testing can be done by looking back in time using images. Indeed, rephotography is a powerful way by which to study landscape change (Rogers et al., 1984), both physical (Harrison, 1950) and ecological (Hart and Laycock, 1996). Some of the earliest photographic documentation is that of G.K. Gilbert, who set up marked stations to document change in glacier extent over time (Gilbert, 1904). His well-documented sites can still be located and, together with his original images, have been used to show the dramatic shrinkage of small alpine glaciers over the past century (Harrison, 1974).

Some geologic studies use a few historic images. For example, the stripping of trees and consequent landscape response in Colorado is documented and quantified by a series of images taken over a 115-year period (Graf, 1979). These images were used along with hydraulic models to explain the distribution of stream incision over time and space. This and many other previous uses of historic imagery have focused on western North America, often concentrating on important natural areas photographed by early explorers (Griffiths et al., 2004; Meagher and Houston, 1998; Stephens and Shoemaker, 1987; Webb, 1996).

Other studies use many images. Meagher and Houston investigated primarily biologic change in Yellowstone through image comparisons from two or three different time periods, usually the late 1800s, and before and after the 1988 fire. Webb's interest is more geologic, as he investigated a century of change in the Grand Canyon by rephotographing images of the Stanton Expedition a century later. Both Webb (1996) and Meagher and Houston (1998) summarize changes in tabular form, and Meagher and Houston go on to do statistical analysis. The analysis of Griffiths et al. (2004) goes a step further. Analyzing over 1300 paired images of scenes first photographed as early as 1871 , they calculate average debrisflow recurrence intervals in the Grand Canyon. Using these data, they develop a regression model suggesting where such flows are most likely to originate.

\section{USING A DIGITAL IMAGE ARCHIVE TO DO SCIENCE}

Widespread adoption of photography in the mid-1800s generated immense numbers of images. Glass plates, negatives, or prints, whether taken of a family picnic by the river or a hotel in the mountains, include far more information and incidental detail than one might suspect, because the resolution of photographic emulsions is so high (Strausz, 2001). For example, images faithfully record in their backgrounds season, vegetation, road types and orientations, stream flows and morphology, and hillslope condition (Fig. 1). Captions and titles can provide even more information, although they may carry the subtle or not-so-subtle biases of the time (Doel and Henson, 2005). Next, we provide three examples of how a searchable Web-based archive can be used to approach scientific and land management questions by analyzing images for the details they contain.

\section{Erosion-The Tree Connection}

Based on contemporary studies (Montgomery et al., 2000) as well as studies of geologic archives (Jennings et al., 2003), we reasoned that more erosion would be recorded in deforested than in forested Vermont landscapes. To test this hypothesis, we searched the Landscape Change Program archive using the keywords clear-cutting, landslide, and erosion. From the search results, we categorized images with respect to date, the amount of tree coverage, the size of the eroded area, and other landscape characteristics, including clear-cut slopes, roads, and farming.

We find an inverse relationship between landscape tree cover and the number of images showing erosion (Fig. 2A), suggesting that relationships determined by modern processes studies hold true over 150 years. Of the 342 images in the Landscape Change Program archive that show erosion, 222 had no trees or almost no trees near the eroded site (65\%). Conversely, only nine images showing erosion had complete forest cover near the eroded site (3\%). Smaller areas of erosion are always more common than larger areas of erosion, no matter what the tree cover. If we normalize for 

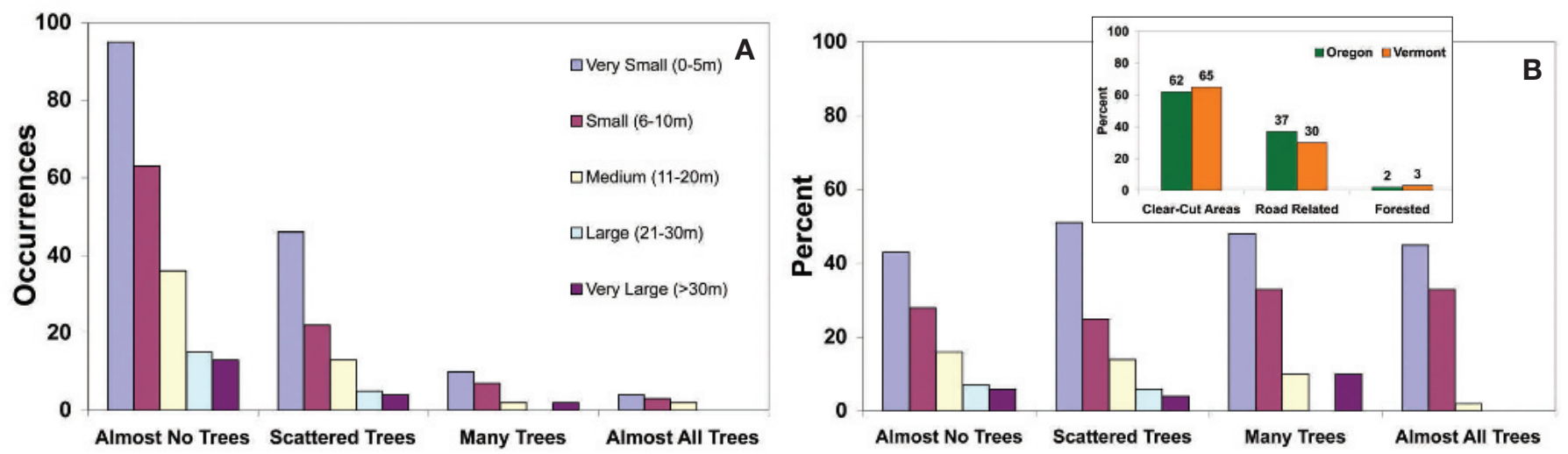

Figure 2. Relationship between tree cover category, erosion, and estimated width of eroded area. (A) Areas of erosion (all width classes) are most common in images with few trees and least common in images with full tree cover. Color key indicates approximate width of eroded area. (B) When normalized for the number of images showing erosion, the size distribution of eroded areas does not depend on the amount of forest cover (i.e., there are fewer large areas of erosion and more small areas of erosion independent of the number of trees on the landscape). Inset compares percentage of images showing erosion classified by land-use/cover classes (Vermont historical image analysis) to percentage distribution of erosion by land-use/cover in Oregon after the intense 1996 storm cycle (Association of Forest Service Employees for Environmental Ethics, 1996). In both studies, the presence of roads and the absence of trees are correlated with erosion.

the frequency of erosion in each tree cover class, the size distributions of erosion areas are similar (Fig. 2B).

From the analysis of these images, we conclude that the removal of woody vegetation from Vermont slopes increased the frequency of erosion. This finding echoes contemporary studies done in the Pacific Northwest (Montgomery et al., 2000) and provides additional support for the suggestion, based on analysis of alluvial fan and lake sediment archives, that New England landscapes eroded rapidly in response to settlement and continued land clearance through the nineteenth century (Bierman et al., 1997; Jennings et al., 2003; Noren et al., 2002). Photographic data from Vermont, spanning nearly 150 years, clearly indicate where, and thus why, such erosion happens (Fig. 2, inset). People catalyze erosion by clearing slopes and building roads (Wemple et al., 2000).

Simple, infinite slope, force-balance models for shallow planar landslides suggest one process by which removal of

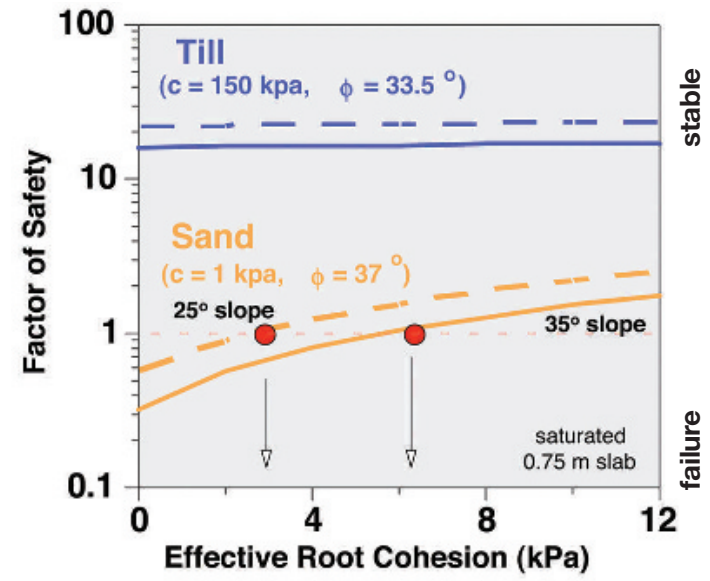

Figure 3. Results of infinite slope stability model. Slopes will fail if factor of safety drops below 1 . Till slopes $\left(25^{\circ}=\right.$ dashed line and $35^{\circ}=$ solid line) have large factors of safety even when saturated and do not fail. Sandy slopes, with little or no cohesion (c), require only the modest effective cohesion provided by tree roots $(3-6 \mathrm{kPa})$ to remain stable when saturated on $25^{\circ}$ (dashed line) to $35^{\circ}$ slopes (solid line). Red dots represent onset of stable conditions; factor of safety (resisting/driving force) $=1$. trees reduces slope stability (Montgomery et al., 2000; Roering et al., 2003). Measurements suggest that tree roots provide 1-12 kPa of effective cohesion (Selby, 1993). Although these values are only a small portion $(<1 \%-30 \%)$ of the cohesion (Selby, 1993) of glacial clay (30-70 kPa) or till (150-250 kPa), so common in New England, calculations show that tree roots provide just enough cohesion to hold steep (25-35'), sandy slopes together and thus prevent shallow landsliding during saturated conditions for low cohesion materials such as sand (Fig. 3). Many nineteenth century images show shallow planar landslides on steep, deforested, sandy Vermont hillslopes (e.g., Fig. 4), landsliding we attribute to the loss of effective root cohesion. The process is simple. People clear trees from

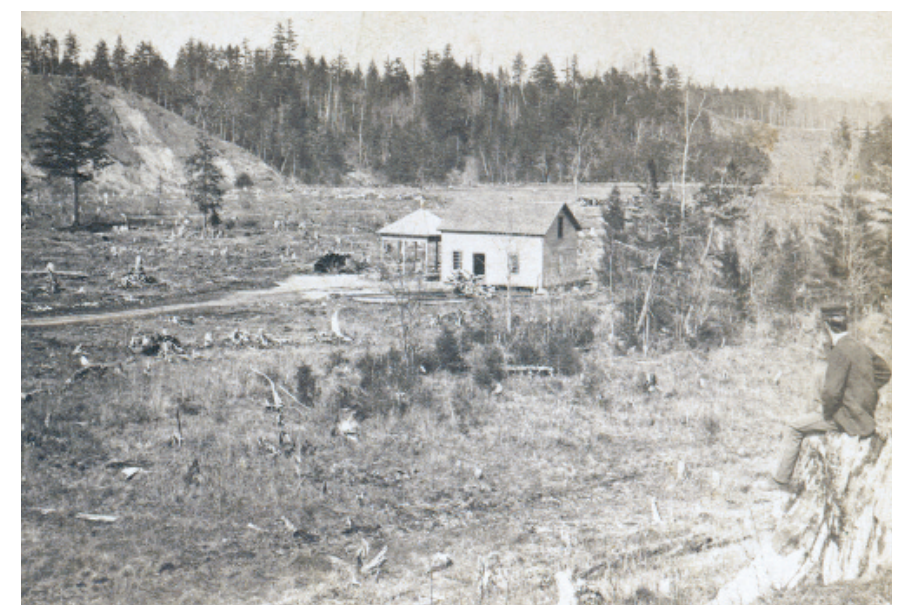

Figure 4. View of clear cut area, Champlain Spring, Highgate, Vermont, late 1800s. In the background are landslides on a steep, cleared slope. Field work suggests failures are in silty, fine sand, glacial lake deposits of the Champlain lowland. These shallow planar slides were likely catalyzed by loss of effective root strength after clear-cutting of the slope (see Fig. 3 ). In the middle ground are many stumps and much slash, the remains of cutting second-growth timber. There is a spring house at the center of the image. Note the tremendous size of the stump on which the man is sitting; it is likely all that remains of the old growth, pre-settlement forest that once covered Vermont lowlands like this. Image property of University of Vermont, Special Collections, Bailey Howe Library (LS03668). 

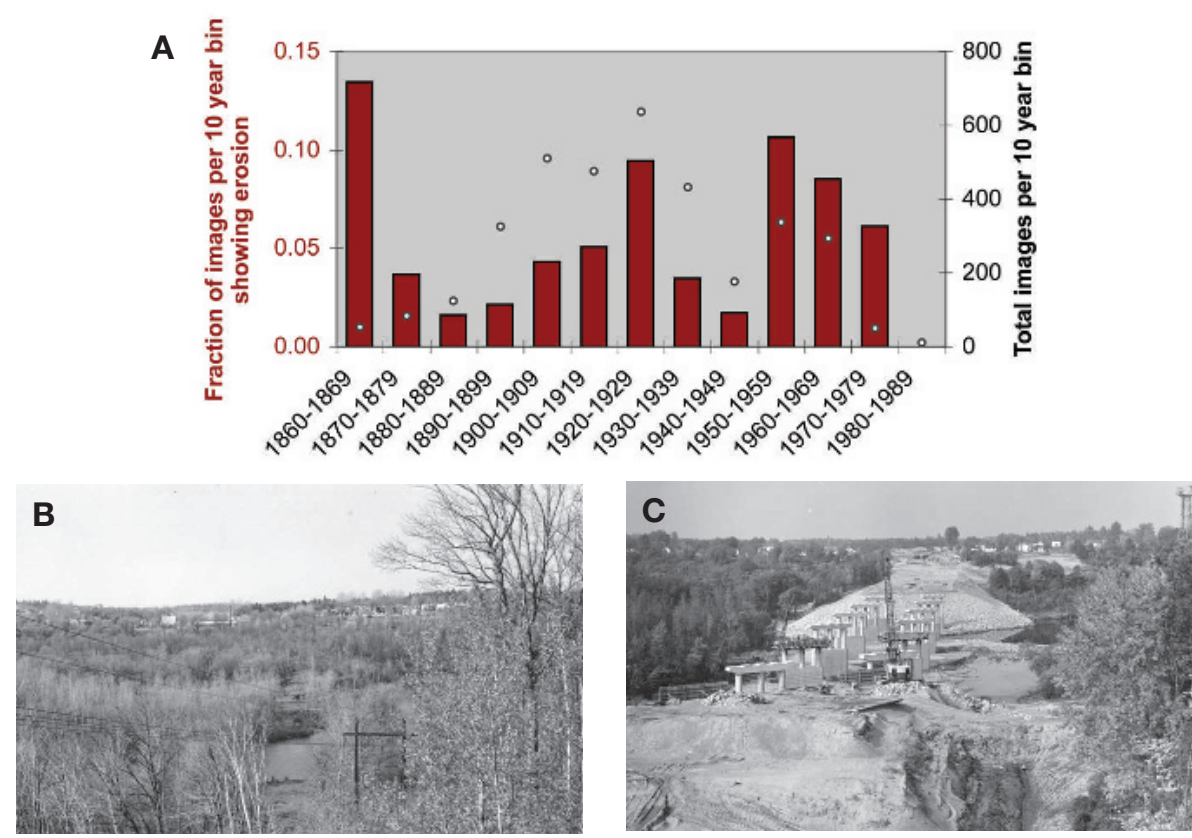

Figure 5. The frequency of images showing erosion has changed over time. (A) Percentage of images in the archive (binned in $10 \mathrm{yr}$ intervals) that show erosion. Open circles show total number of images per bin. (B) Photograph (May 11, 1961) of South Burlington before interstate construction showing wooded slopes above Winooski River. (C) Same view as B but during construction of I-89 (Oct. 10, 1961), showing scale of disturbance and erosion related to road building. Images by D. Wiedenmayer; property of Vermont State Archives.
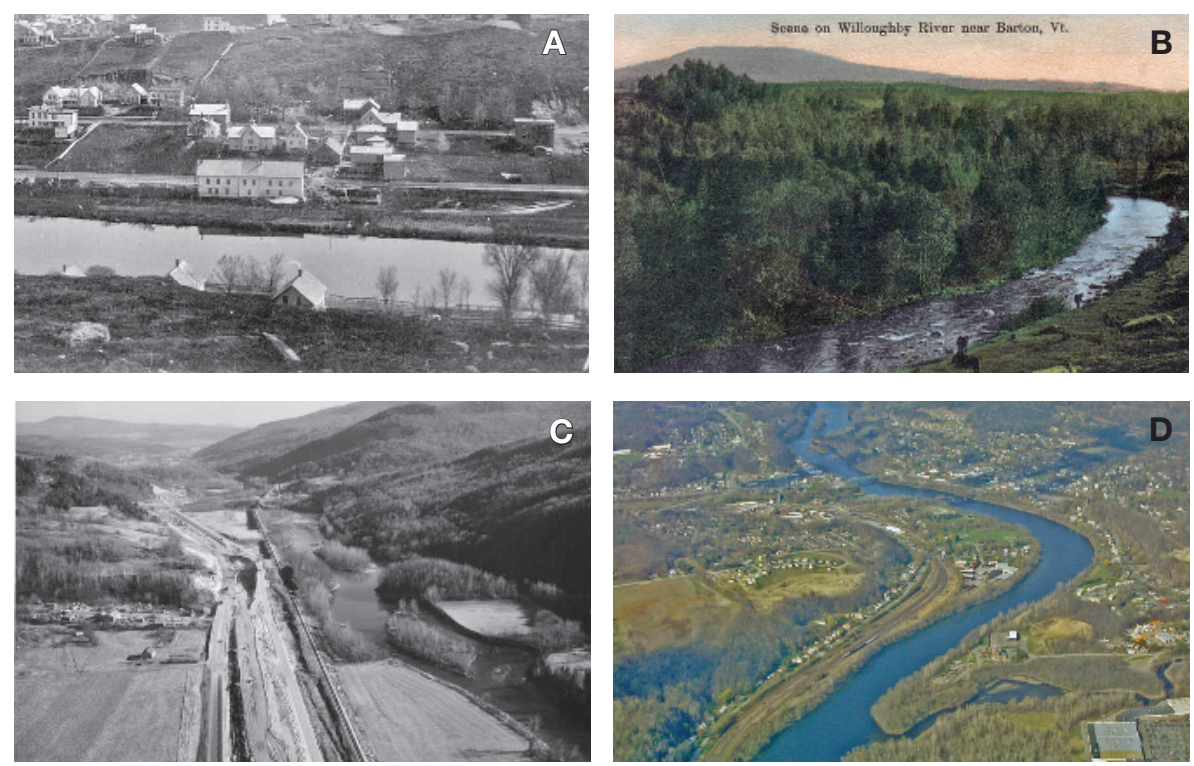

Figure 6. Examples of riparian zone images used to calculate riparian buffer quality index. (A) Category 1 (score $=1$ pt): no riparian buffer. Montpelier, Vermont (LS04060; no date). View across the Winooski River from a farm field. Note large glacial erratics in foreground. Image property of Vermont Historical Society. (B) Category 2 (score $=2 \mathrm{pt}$ ): $\leq 50 \%$ riparian buffer. Barton, Vermont (LS03795; no date). Image shows a bend in a river with complete riparian buffer on the left and no buffer on the right. Grazing cows on the cleared bank keep pasture open. Image property of Old Stone House Museum. (C) Category 3 (score $=3 \mathrm{pt}$ ): $>50 \%$ riparian buffer. Bolton, Vermont (LS06204; 1960). Oblique aerial photo shows the construction of I-89 at Bolton flats. Winooski River at right. Farms and fields in the valley bottom with extensive riparian buffer. Image property of Vermont State Archives. (D) Category 4 (score $=4 \mathrm{pt}$ ): 100\% riparian buffer. Hartford, Vermont (LS01482, 2004). A full riparian buffer is present along both sides of the Connecticut River. slopes and keep the slopes clear for grazing, preventing regrowth of new trees and new roots. Once the old roots rot or the stumps are pulled, root strength is gone, and the treeless hillslopes are primed for failure, awaiting only a storm large enough to saturate the ground (D'Odorico and Fagherazzi, 2003).

The distribution over time of images depicting erosion reveals relationships to both significant natural and human events and suggests the influence of major cultural transitions. The frequency distribution of erosion images has three peaks (the 1860s, the 1920s, and the 1960s; Fig. 5A). The first peak just predates maximum land clearance in Vermont. The second peak is coincident with the 1927 flood of record, and the third peak occurs during construction of the interstate highway system. Broader cultural changes also influence the timing of erosion maxima. The steady rise in the frequency of erosion images from 1900 to 1930 probably reflects the advent of the automobile and the road building and improvement that followed. Similarly, we suspect that the rapid rise in erosion frequency after 1960 and the slow decline thereafter reflects the massive land disturbance occasioned by building the interstate highways (Fig. 5B and 5C).

\section{Riparian Buffers-Coming Back}

Riparian buffers, the woody vegetation found along streams and rivers, serve a number of important roles, including stabilization of stream banks, moderation of stream flow, provision of habitat, and recruitment sources for large woody debris (Abbe and Montgomery, 1996; Wagner, 1999). Buffers are often destroyed by agriculture and forestry practices (Robbins, 1997) as well as by residential development. Although riparian zones are the focus of extensive protection and restoration efforts (Langston, 2003), there appears to be little documentation of how the extent of buffers has changed over decadal timescales.

We analyzed over 400 photographs of streams and rivers from the Landscape Change Program archive to determine how the continuity of woody riparian buffer vegetation changed over the past 150 years. To quantify change over 

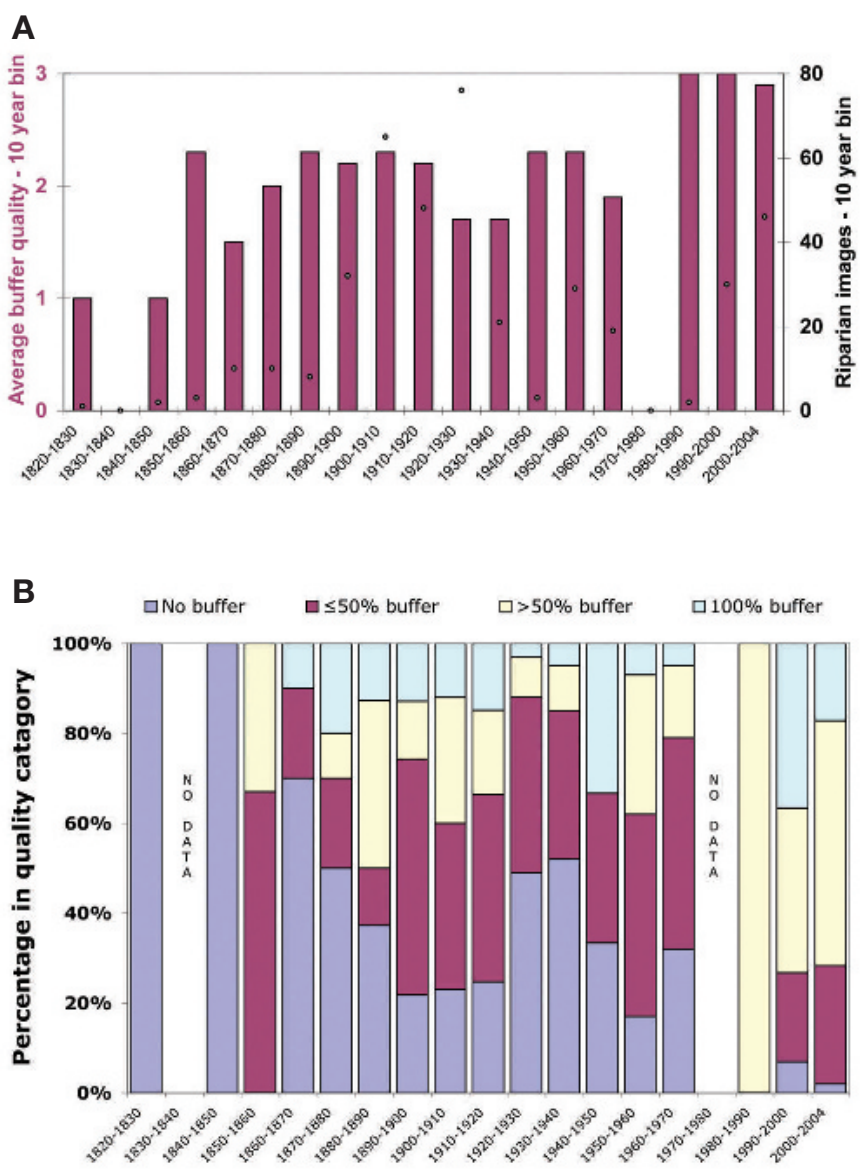

Figure 7. Riparian zone quality has changed over time. (A) Between 1850 and 1970, the average riparian zone quality index (shown by plum bars) varied between 1.5 and 2.3; after 1980, the index rises to $\sim 3$. Black circles indicate number of images analyzed per $10 \mathrm{yr}$ bin. Riparian images not available for times with no data. (B) The distribution of riparian zone quality in Vermont has changed through time. The prevalence of river margins with no buffer decreased between 1850 and today. In the past 25 $\mathrm{yr}$, the prevalence of river margins with $>50 \%$ tree cover has increased.

time, we defined a riparian buffer quality index, in which images showing no buffer (Fig. 6A) were assigned to category 1 (and given a score of 1). Images showing a fully forested buffer along the river or stream banks were assigned a rank and score of 4 (Fig. 6D). Sorting the images by decade, we calculated an average quality index for every $10 \mathrm{yr}$ interval (Fig. 7A).

Dozens of nineteenth century images document riparian zones along Vermont streams with little or no buffering by woody vegetation. Similar impacts on riparian zones from settlement, agriculture, mining, and forestry practices in the 1800s and early 1900s have been noted in the Pacific Northwest (Langston, 2003; Robbins, 1997; Taylor, 1999). The continuity of vegetated, riparian zone buffers along Vermont streams and rivers has improved over time; specifically, the prevalence of river margins with no buffer at all (category 1) decreased over the past 150 years (Fig. 7B). The decrease in completely cleared riparian zones may reflect the move away from wood as both a source of energy and as the dominant structural material for building and fencing (Robbins, 1997).
From 1850 to 1970 , the average riparian buffer quality index we defined varied between 1.5 and 2.3 with no trend. After 1980, the average rose and remained at $\sim 3$, a substantial increase (Fig. 7A). This step-function increase in the riparian vegetation quality index occurred during the 1980s, 20 years after community forests were planted, the environmental movement started, and the decline of the Vermont dairy farm began. In the past 25 years, the prevalence of river margins with greater than 50\% tree cover has also increased. A similar trend of recently increased riparian vegetation has been identified by analyzing >3000 repeat photography images from the southwestern United States (Webb and Leake, 2005).

The in-stream effects of increasing riparian zone vegetation could be significant. Although it may not be possible to tease apart the effects of changing sediment delivery over time related to reforestation (Trimble, 1999) and watershed development (Wolman and Schick, 1967), the increase in riparian buffer zone continuity over time is likely to affect channel geometry, including width and depth (Hession et al., 2003; Trimble, 1997), as well as improve aquatic ecosystem function (Sweeney et al., 2004).

\section{Characterizing Flood Effects}

In 1927, a November flood, with peak flows typically two times higher than other recorded events, struck Vermont (http://www.uvm.edu/perkins/landscape/1927_flood/flood. htm). The flood destroyed more than 1000 bridges and caused significant channel change and channel bank erosion. October 1927 had been very wet, leaving soils saturated. The storm dropped up to $22 \mathrm{~cm}$ of rain in central Vermont, with at least $12.5 \mathrm{~cm}$ falling over most of the state (National Weather Service, 2002). Within days of the devastating flood, the U.S. Army flew over Vermont, photographing the damage. Of the 90 images taken, 67 are extant. During the summer of 2004, these 67 historical images were rephotographed to show the changes in riparian corridors, development, and channel characteristics. We also examined hundreds of ground-level images taken both during and after the flood. Many of these images allow identification of flood heights; river stage determined this way is a valuable tool for flood hazard evaluation.

Modern rephotography of flood and post-flood aerial images allows us to quantify changes that have occurred since 1927 (Fig. 8). Examination of the 67 pairs of aerial images shows that between 1927 and 2004, forest cover increased in $70 \%$ of the images, new roads were built in almost $60 \%$, development altered the landscape in almost 50\%, and vegetation cover in riparian zones increased in over 60\% of the images. These changes have differing effects on surface water hydrology, with reforestation tending to reduce peak flows and storm flow volumes, whereas development and road building both tend to increase runoff and storm peaks (Dunne and Leopold, 1978). The increase in riparian zone cover is consistent with the data from ground photos (Fig. 7).

\section{IMPLICATIONS}

The rapid expansion of the World Wide Web, and the consequent ability of anyone to find and analyze large numbers of images, opens up a new way of looking at landscapes over space and time (see GSA Data Repository Item Table 

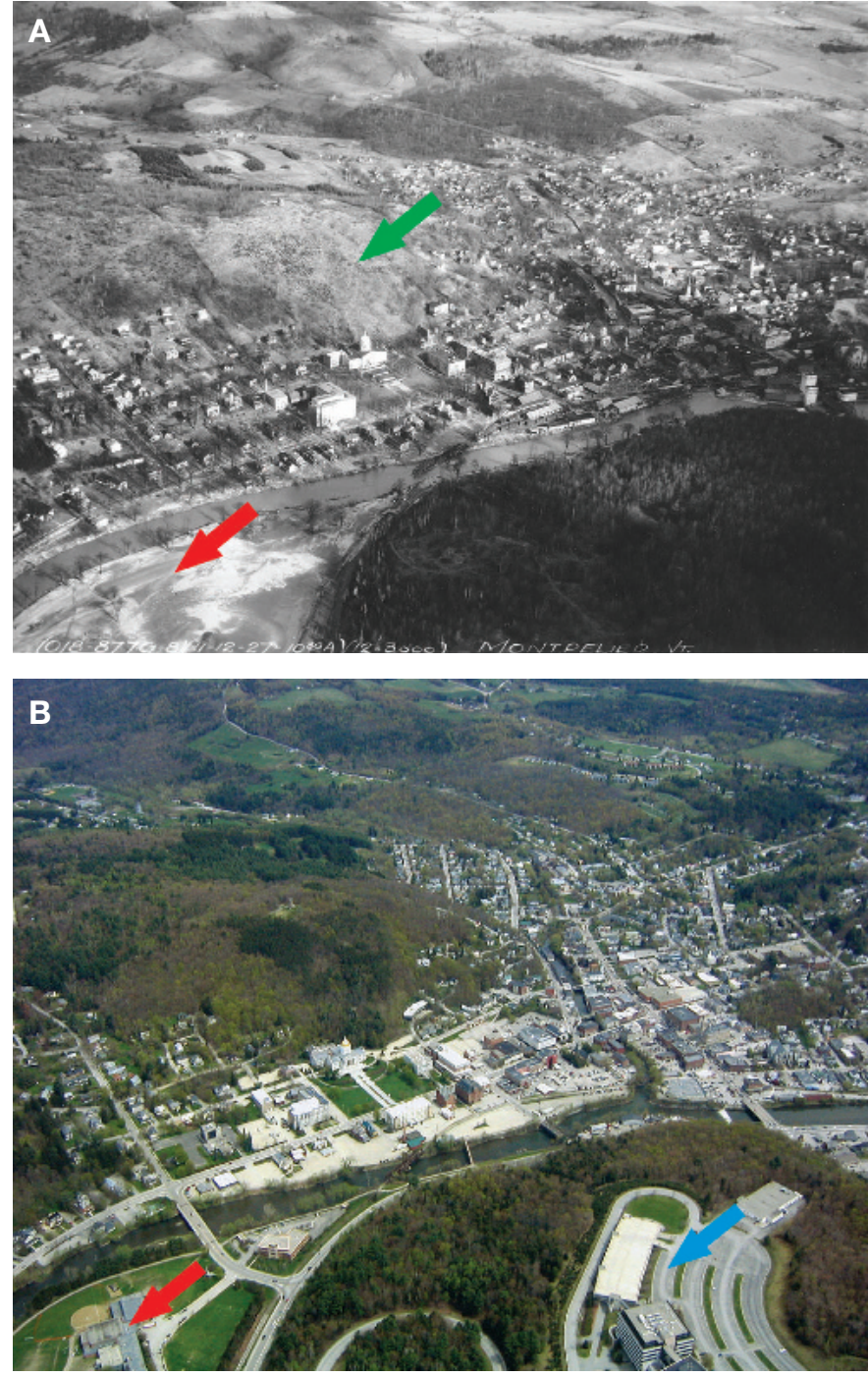

$\mathrm{DR} 1^{1}$ for examples of online image archives). In this paper, we present several examples of science that can now be done because such image archives exist. Without the ability to study at least hundreds of relevant images, results such as those we present would have little statistical significance.

As online archives grow in popularity and size, similar types of analyses should be feasible all over the world, with increasing statistical power as sample sizes grow larger. The range of image-based, interdisciplinary research projects that can be undertaken will increase. Images could be used to examine tree species distribution over time in response to landscape disturbance (Cogbill et al., 2002), link landscape disturbance to changing settlement dynamics (Wessels, 1999), and find long-ago-demolished gasoline stations to map the distribution of environmentally hazardous, abandoned underground storage tanks (Vermont Agency of Natural Resources, 2004, personal commun.).

The approach we describe here could be replicated in other physiographic provinces and climatic zones. Research questions would differ in arid, tropical, or subpolar regions,
C

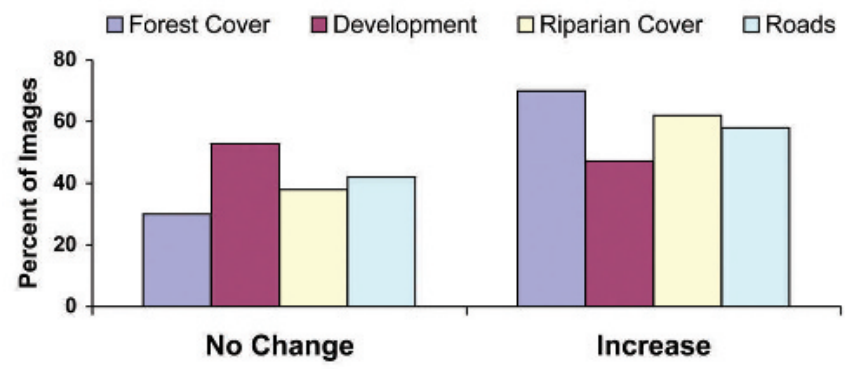

Figure 8. Paired oblique aerial images of Montpelier including the Winooski River. (A) Photograph from several days after the 1927 flood shows overbank deposits alongside the channel and over point bars (red arrow). Much of the hills remain deforested, including the area behind the Vermont State House (green arrow). All bridges over the river have been destroyed. LS01429, image property of Special Collections, Bailey Howe Library, University of Vermont. (B) Similar view photographed in summer 2004. Significant reforestation has covered many slopes with trees. A high school now occupies the point bar (red arrow) and forest cover in the lower right is broken by parking lots and a large office complex (blue arrow). Bridges again cross the river and the riparian zone is better vegetated. (C) Characterization of image pairs $(n=67)$ showing percentage in which characteristics studied (forest cover, development, riparian cover, and roads) either remained similar (no change) or increased.

and the length of the photographic record varies from place to place, but much of the world has archives of landscape images. These images, as they move out of attics, onto the Web, and into the hands of natural scientists and others, have many important geologic, environmental management, and ecologic stories to tell. The impact of such research could be very broad, encompassing related disciplines such as historical ecology (Cronon, 1983; Russell, 1998) and the historical evolution of human-landscape interaction over time (Nash, 1967).

\section{ACKNOWLEDGMENTS}

The Landscape Change Program is supported by Lintilhac and National Science Foundation grants EAR-9907724 and EAR-0122005, including a Research Experience for Undergraduates supplement. We thank L. Mallard, D. Elvin, W. Wright, L. Persico, C. Burns, G. Sanford, C. Manduca, C. Carter, S. Snyder, M. McGee, and K. Lenorovitz for their contributions to this project. Insightful reviews by R. Webb, T. Hanks, K. Howard, and R. Doel greatly improved earlier versions of this paper.

\section{REFERENCES CITED}

Abbe, T.B., and Montgomery, D.R., 1996, Large woody debris jams, channel hydraulics and habitat formation in large rivers: Regulated Rivers: Research Management, v. 12, p. 201-221 Association of Forest Service Employees for Environmental Ethics, 1996, Aerial landslide survey of Mapleton Ranger District following rainstorm of February, 1996: http://www. umpqua-watersheds.org/local/landslides/slides.html\#afsee.

Bierman, P., Lini, A., Davis, P.T., Southon, J., Baldwin, L., Church, A., and Zehfuss, P., 1997 Post-glacial ponds and alluvial fans: Recorders of Holocene landscape history: GSA Today, v. 7 , no. 10 , p. $1-8$.

Cogbill, C.V., Burk, J., and Motzkin, G., 2002, The forests of presettlement New England USA: Spatial and compositional patterns based on town proprietor surveys: Journal of Biogeography, v. 29, p. 1279-1304, doi: 10.1046/j.1365-2699.2002.00757.x.

${ }^{1}$ GSA Data Repository Item 2005065, Table DR1, Examples of online image archives potentially useful for geologic analysis, is available on request from Documents Secretary, GSA, P.O. Box 9140, Boulder, CO 80301-9140, USA, editing@geosociety.org, or at www.geosociety.org/pubs/ft2005.htm. 
Cronon, W., 1983, Changes in the land: Indians, colonists, and the ecology of New England: New York, Hill and Wang, $257 \mathrm{p}$

Cronon, W., 1996, Uncommon ground: Rethinking the human place in nature: New York, W.W. Norton, 561 p.

D'Odorico, P., and Fagherazzi, S., 2003, A probabilistic model of rainfall-triggered shallow landslides in hollows: A long-term analysis: Water Resources Research, v. 39, no. 9, doi: 10.1029/2002WR001595

Doel, R.E., and Henson, P.M., 2005, Reading photographs: Photographs as evidence in writing the history of modern science, in Doel, R.E., and Söderqvist, T., eds., The historiography of recent science, medicine, and technology: Writing recent science: London, Routledge, in press.

Dunne, T., and Leopold, L.B., 1978, Water in environmental planning: New York, W.H. Freeman and Company, 818 p.

Gilbert, G.K., 1904, Variations of Sierra glaciers: Sierra Club Bulletin, v. 5, no. 1, p. 20-25.

Graf, W.L., 1979, Mining and channel response: Annals of the Association of American Geographers, v. 69, no. 2 , p. 262-275.

Griffiths, P.G., Webb, R.H., and Melis, T.S., 2004 Frequency and initiation of debris flows in Grand Canyon, Arizona: Journal of Geophysical Research, v. 109, doi: 10.1029/2003JF000077.

Harrison, A.E., 1950, Glaciers then and now: Sierra Club Bulletin, v. 35, no. 6, p. 111-116.

Harrison, A.E., 1974, Reoccupying unmarked camera stations for geological observations: Geology, v. 2, p. 469-471, doi: 10.1130/0091-7613(1974)22.0.CO;2

Hart, R.H., and Laycock, W.A., 1996, Repeat photography on range and forest lands in the western United States: Journal of Range Management, v. 49, p. 60-67.

Hession, W.C., Pizzuto, J.E., Johnson, T.E., and Horwitz, R.J., 2003, Influence of bank vegetation on channel morphology in rural and urban watersheds: Geology, v. 31, p. 147-150.

Hooke, R.L., 1994, On the efficacy of humans as geomorphic agents: GSA Today, v. 4, no. 9, p. 217, 224-225.

Hooke, R.L., 2000, On the history of humans as geomorphic agents: Geology, v. 28, p. 843-846, doi: 10.1130/00917613(2000)0282.3.CO;2.

Jennings, K., Bierman, P., and Southon, J., 2003, Timing and style of deposition on humid-temperate fans,

Vermont, United States: Geological Society of America

Bulletin, v. 115, p. 182-199, doi: 10.1130/0016-

7606(2003)1152.0.CO;2.
Langston, N., 2003, Where land and water meet: A western landscape transformed: Seattle, University of Washington Press, $230 \mathrm{p}$.

Marsh, G. P., 1864, Man and Nature, Physical Geography as modified by human action: New York, Scribner, $560 \mathrm{p}$.

Meagher, M., and Houston, D.B., 1998, Yellowstone and the biology of time: Photographs across a century: Norman, University of Oklahoma Press, $287 \mathrm{p}$

Montgomery, D.R., 2004, Geology, geomorphology, and the restoration ecology of salmon: GSA Today, v. 14, no. 11 p. 4-12, doi: 10.1130/1052-5173(2004)0142.0.CO;2.

Montgomery, D.R., Schmidt, K.M., Dietrich, W.E., and Greenberg, H.M., 2000, Forest clearing and regional landsliding in the Pacific Northwest: Geology, v. 28, p. 311-314, doi: 10.1130/0091-7613(2000)0282.3.CO.2.

Nash, R., 1967, Wilderness and the American mind: New Haven, Yale University Press, 413 p.

National Weather Service, 2002, The Flood of 1927, http:/ www.erh.noaa.gov/btv/html/27flood.shtml.

Noren, A.J., Bierman, P.R., Steig, E.J., Lini, A., and Southon J., 2002, Millennial-scale storminess variability in the northeastern United States during the Holocene epoch: Nature, v. 419, p. 821-824, doi: 10.1038/nature01132.

Robbins, W.G., 1997, Landscapes of promise: The Oregon story, 1800-1940: Seattle, University of Washington Press, $392 \mathrm{p}$

Roering J.J., Schmidt, K.M., Stock, J.D, Dietrich, W.E and Montgomery, D.R., 2003, Shallow landsliding, root reinforcement, and the spatial distribution of trees in the Oregon Coast Range: Canadian Geotechnical Journal, v. 40, p. 237-253, doi: 10.1139/t02-113.

Rogers, G.F., Malde, H.E., and Turner, R.M., 1984 Bibliography of repeat photography for evaluating landscape change: Salt Lake City, University of Utah Press, 179 p.

Russell, E.W.B., 1998, People and the land through time: Linking ecology and history: New Haven, Yale University Press, $324 \mathrm{p}$.

Schneiderman, J., 2000, The Earth around us: Maintaining a livable planet: New York, W.H. Freeman, 455 p.

Selby, M.J., 1993, Hillslope Materials and Processes: Oxford, Oxford University Press, 466 p.

Stephens, H.G., and Shoemaker, E.M., 1987, In the footsteps of John Wesley Powell: An album of comparative photographs of the Green and Colorado Rivers, 1871-1872 and 1968: Boulder, Colorado, Johnson Books, 286 p.
Strausz, D.A., 2001, Application of photogrammetric techniques to the measurement of historic photographs: http:// oregonstate.edu/instruct/geo422/522nofig.pdf.

Sweeney, B.W., Bott, T.L., Jackson, J.K., Kaplan, L.A. Newbold, J.D., Standley, L.J., Hession, W.C., and Horwitz, R.J., 2004, Riparian deforestation and stream channel narrowing: Loss of stream ecosystem and its services: Journal of the National Academy of Sciences, v. 101, no. 39, p. 14,132-14,137, doi: 10.1073/pnas.0405895101.

Taylor, J.E., 1999, Making salmon: An environmental history of the Northwest fisheries crisis: Seattle, University of Washington Press, 421 p.

Trimble, S.W., 1997, Stream channel erosion and change resulting from riparian forests: Geology, v. 25, p. 467-469, doi: 10.1130/0091-7613(1997)0252.3.CO;2.

Trimble, S.W., 1999, Decreased rates of alluvial sediment storage in the Coon Creek Basin, Wisconsin 1975-93: Science, v. 285, p. 1244-1246, doi: $10.1126 /$ science.285.5431.1244.

Wagner, S., 1999, A review of the scientific literature on riparian buffer width, extent and vegetation: Office of Public Service and Outreach Institute of Ecology University of Georgia.

Webb, R.H., 1996, Grand Canyon: A century of change: Tucson, University of Arizona Press, $290 \mathrm{p}$.

Webb, R.H., and Leake, S.A., 2005, Ground-water surfacewater interactions and long-term change in riverine riparian vegetation in the southwestern United States: Journal of Hydrology, in press.

Wemple, B.C., Swanson, FJ., and Jones, J.A., 2000, Forest roads and geomorphic process interactions, Cascade Range, Oregon: Earth Surface Processes and Landforms, v. 26, no. 2, p. 191-204.

Wessels, T., 1999, Reading the forested landscape: A natura history of New England: Woodstock, Countryman Press, $199 \mathrm{p}$.

Wolman, M.G., and Schick, A.P., 1967, Effects of construction on fluvial sediment, urban and suburban areas of Maryland: Water Resources Research, v. 3, no. 2, p. $451-464$

Zheng, X., and Eltahir, E.A.B., 1997, The response to deforestation and desertification in a model of West African monsoons: Geophysical Research Letters, v. 24, no. 2, p. 155-158, doi: 10.1029/96GL03925.

Manuscript received December 6, 2004; accepted January 4, 2005. (-)

\section{To submit your abstract, to register, or to sign up for e-news, visit www.geosociety.org/meetings/esp2/.}

